\title{
Covid-19 Lockdown Challenges or New Era for Higher Education
}

\section{Las complejidades de la cuarentena de Covid-19 o una nueva era de educación superior}

\section{Iryna Didenko}

$\mathrm{PhD}$ in Education, Associate Professor of the Department of Foreign Languages of the Faculty of Economics of Taras Shevchenko National University of Kyiv, Ukraine.

ORCID: https://orcid.org/0000-0003-2047-7239

\section{Olena Filatova}

$\mathrm{PhD}$ in Linguistics, Assistant Professor of the Department of Foreign Languages of the Faculty of Economics of Taras Shevchenko National University of Kyiv, Ukraine.

ORCID: https://orcid.org/0000-0001-7585-3938

\section{Lyudmyla Anisimova}

$\mathrm{PhD}$ in Physics and Mathematics Associate Professor, Deputy Dean of the Faculty of Economics of Taras Shevchenko National University of Kyiv, Ukraine.

ORCID: https://orcid.org/0000-0001-9678-269X

*Correspondence

Email: ivannovadremova29@gmail.com
Cite as:

Didenko, I., Filatova, O., Anisimova, L. (2021). Covid-19 Lockdown Challenges or New Era for Higher Education. Propósitos y Representaciones, 9 (SPE1), e914. Doi: http://dx.doi.org/10.20511/pyr2021.v9nSPE1.914

(C) Universidad San Ignacio de Loyola, Vicerrectorado de Investigación, 2021. 


\section{Summary}

The COVID-19 lockdown caused hard time for higher education: unexpected shift to online. This research was conducted among 50 first-year Bachelor's Degree students and 50 first-year Master's Degree students of the Faculty of Economics of Taras Shevchenko National University of Kyiv. The objective of the study was to identify the challenges that each focus group faced and students' satisfaction rate in education under lockdown. Quantitative methods were used for collecting data and Excel tools for processing the results The findings demonstrated relatively average satisfaction rate among the 1st-year Bachelor level students due to a number of factors: lack of self-study skills, lack of background, lack of experience. However, 1st-year Master level students demonstrated relatively high satisfaction rate. The reason for this is that they are quite experienced and competent, therefore, they require less facilitation from the professors, their background knowledge is enough to allow them to search the necessary data in the Internet, their analytical and reasoning skills are developed enough to let them process obtained information, critically evaluate it and produce reasonable conclusions. The findings of this research allow to assume that after lockdown it might be worth reconsidering the format of learning for Master's Degree Programs and shift from conventional face-to-face learning to blended or even distance learning.

Key Words: COVID-19 lockdown, distance learning, emergency e-learning, higher education, students' satisfaction rate.

\section{Resumen}

La cuarentena de COVID-19 causó dificultades para la educación superior: cambio inesperado a Internet. Esta investigación se llevó a cabo entre 50 estudiantes de primer año de licenciatura y 50 estudiantes de primer año de maestría de la Facultad de Economía de la Universidad Nacional Taras Shevchenko de Kiev. El objetivo del estudio fue identificar los desafíos que enfrentó cada grupo focal y el índice de satisfacción de los estudiantes en la educación bajo cuarentena. Se utilizaron métodos cuantitativos para recopilar datos y herramientas de Excel para procesar los resultados.Los hallazgos demostraron una tasa de satisfacción relativamente promedio entre los estudiantes de primer año de licenciatura debido a una serie de factores: falta de habilidades de autoaprendizaje, falta de antecedentes, falta de experiencia . Sin embargo, los estudiantes de primer año de maestría demostraron una tasa de satisfacción relativamente alta. La razón de esto es que son bastante experimentados y competentes, por lo tanto, requieren menos facilitación por parte de los profesores, su conocimiento previo es suficiente para permitirles buscar los datos necesarios en Internet, sus habilidades analíticas y de razonamiento están lo suficientemente desarrolladas para permitirles Ellos procesan la información obtenida, la evalúan críticamente y producen conclusiones razonables. Los hallazgos de esta investigación permiten suponer que después de la cuarentena podría valer la pena reconsiderar el formato de aprendizaje para los programas de maestría y pasar del aprendizaje convencional presencial al aprendizaje combinado o incluso a distancia.

Palabras clave: cuarentena de COVID-19, aprendizaje a distancia, aprendizaje electrónico de emergencia, educación superior, índice de satisfacción de los estudiantes.

\section{Introduction}

COVID-19 lockdown has demonstrated the real picture of the current situation with higher education: progressive universities functioning in the 20 -s of the $21^{\text {st }}$ century appeared not to be ready to implement digital teaching and learning tools, the existent online learning platforms turned out to be not universal remedies, teaching staff were not ready to teach distantly, sometimes their understanding of online teaching was limited to sending handbooks, slides, sample tasks and assignments to the students via email and setting deadlines for submission of the performed tasks. Such unpreparedness sounded strange if to take into consideration that introduction of 'emergency e-learning' (Murphy, 2020) in higher education appeared not for the first time: Michael P. A. 
Murphy (2020), a Canadian researcher from University of Ottawa, mentioned at least 2 similar situations: introduction of distant learning in Texas in 2005 due to damaged by Katrina hurricane colleges and quarantine on H1N1 in 2009. Laura Czerniewicz (2020), a researcher from the University of Cape Town (South African Republic), also wrote about lessons that should have been learned from lockdowns in 2015 - 2017, when due to a number of 'student-led protests' 27 universities of the country ceased their face-to-face learning process. In Ukraine in 2009 also a 3week quarantine because of $\mathrm{A} / \mathrm{H} 1 \mathrm{~N} 1$ was announced and all the educational institutions quitted face-to-face learning for 3 weeks (Shyshatskiy, 2020). Also short-term lockdowns are announced in Ukraine almost every year due to flu epidemic.

However, according to some researchers 'emergency e-learning has nothing in common with online learning' (Myths about online learning, 2020). The situation occurred in spring 2020, when all the face-to-face classes were unexpectedly transferred online and lecturers had to adjust their courses to online learning, to master online teaching skills and urgently familiarize themselves with online platforms and applications, is more about emergency learning rather than distance learning, when the curricula were developed from the very beginning for online learning, considering all the aspects of such format.

Emergency e-learning is sometimes called 'emergency remote teaching', because it is more about delivering instructions rather than achieving learning outcomes by the students (Hodges et al, 2020). The researchers: Hodges et al. (2020) think that we should not only distinguish between 'emergency remote teaching' and online learning, but also analyze carefully pros and cons of the shutdown 2020 for learning and next time be well-prepared to face quarantine measures without losing quality of education.

However, in the majority researches devoted to education during lockdown 2020 'emergency e-learning' is replaced by the term 'distance learning', namely, in different fields of education: in Chemistry (Domenici, 2020), in Medicine (Hilburg et al, 2020), in Dental education (Bennardo et al, 2020), in Economics (Mohammad, 2020); as well as in researches on education under pandemic in different countries: Poland (Rizun and Strzelecki, 2020), Georgia (Basilaia et al, 2020), Turkey (Bostan et al, 2020), and Czech Republic (Brom et al, 2020). Thus, here in this research we also use the same terminology for analysis of the situation with higher education in the field of Economics in Ukraine in the lockdown period.

This paper looks at challenges $1^{\text {st }}$ year students of Bachelor's Degree and Master's Degree programs faced during so-called distance learning phase, analyzes their satisfaction rate and figures out prospects for higher education development relying upon learners' needs.

\section{Theoretical framework}

The advantages and disadvantages of distance learning have become the object of a number of researches.

If to speak about positive moments, one of the undeniable benefits of distance learning is its accessibility for a great variety of learners, no matter what their reasons for missing face-toface lessons are: health problems, remote location, busy timetable (Arkorful \& Abaidoo, 2015; Ocak, 2020).

Possibility for the learners to study 'at their own pace', namely, to choose the amount of time they spend on the tasks, to start learning in the reversed order: 'from the end rather than the beginning', to organize their learning themselves, also sounds as a nice advantage of the distance learning (Howard \& McGrath, 1995; O'Lawrence, 2005; Radović-Marković, 2010; Arkorful et al, 2015; de Oliveira \& Penedo, 2018). 
Next benefit of the online-learning is student-centeredness. Students have 'more control on their studies, on the content', and on the depth of the subject they want to learn (Howard et al, 1995; O'Lawrence, 2005; de Oliveira et al, 2018; Moroz et al, 2019).

During distance learning learners have wider exposure to real context in terms of more opportunities for them to 'use resources outside the classroom', that also brings more points to the advantages of such kind of learning (Howard et al, 1995; Arkorful et al, 2015).

Cost-effectiveness of online-learning cannot be denied: no travel costs, less premises for bigger amount of learners (O'Lawrence, 2005; Posey et al, 2010; Radović-Marković, 2010; Arkorful et al, 2015; de Oliveira et al, 2018).

Also distance learning resolves the problems with the lack of teaching professionals (Arkorful et al, 2015).

Among the obvious disadvantages of distance learning lack of communication is considered to be the biggest This negative point brings one more disadvantage, namely, difficulty to 'build social links' (Howard et al, 1995; O'Lawrence, 2005; Posey et al, 2010; Arkorful et al, 2015).

Opportunity 'to choose the own pace' for the learners has another side of the coin: it is very hard to have the group lessons in this situation, because all the learners might appear at the different stages of the course (Howard et al, 1995). Also students might be more reluctant to learning due to less control and big volume of self-work required from them (O'Lawrence, 2005; de Oliveira et al, 2018).

Accessibility of the outside resources might cause the distance learning to be more timeconsuming than face-to-face learning (Howard et al, 1995; Posey et al, 2010).

During the online-learning teachers 'have less tools for monitoring students' progress and performance', students' cheating is also difficult to avoid (Howard et al, 1995; Arkorful et al, 2015).

Two more disadvantages are as follows: 'traditional teaching methods might be less effective' in online-learning, as well as 'not every discipline can be effectively taught' via online methods (Arkorful et al, 2015). Thus, even experienced teachers might appear pretty inexperienced in distance learning (O'Lawrence, 2005; Posey et al, 2010; Borodavko, Silkin, Shakhmatov \& Chelysheva, 2020).

Technical problems during online-lessons might also be an obstacle for getting the right instructions and obtaining knowledge (O'Lawrence, 2005).

As can be judged from the analysis of the existent research findings positive moments of distance learning usually might appear to be pretty relative, because almost all of them have another side of the coin - negative consequences or challenges.

The current research studied the impact of distance learning on the quality of tertiary education under 2020 pandemic emergency learning in terms of the pros and cons of onlinelearning outlined by the students of one of the cutting-edge universities of Ukraine. This analysis helped to outline future perspectives of tertiary education. 


\section{Methodology}

This research was conducted among $501^{\text {st }}$-year Bachelor's Degree students and $501^{\text {st }}$-year Master's Degree students of the Faculty of Economics of Taras Shevchenko National University of Kyiv. The objective of the study was to identify the challenges that each focus group faced and students' satisfaction rate in education under lockdown. Quantitative methods were used for collecting data and Excel tools for processing the results. In the survey multiple-choice, closeand open-ended questions were used.

The survey questions were formulated as follows:

- What is the level of your satisfaction with educational process during the distance learning mode?

extremely satisfied / quite satisfied / satisfied / fairly satisfied / not satisfied

- How sufficient was the theoretical material given to you during the distance learning mode?

absolutely enough / quite enough / enough / fairly enough / not enough

- How satisfied with the assessment were you during the distance learning mode?

extremely satisfied / quite satisfied / satisfied / fairly satisfied / not satisfied

- What were the means of communication between you and your teachers during the distance learning mode?

- What difficulties have you faced with during the distance learning mode?

\section{Results and discussion}

Such a durable lockdown was experienced for the first time that is why, first of all, in the research we were interested if our students were satisfied with the educational process organized under COVID total shutdown. Thus, at the beginning of the survey the participants were asked to identify the overall level of their satisfaction with distance learning. If to judge from the results of the research, the $1^{\text {st }}$-year Master's Degree students, namely $88 \%$ of them, demonstrated higher level of satisfaction: between extremely satisfied and quite satisfied, however, whereas, $62 \%$ of the $1^{\text {st }}$-year Bachelor's Degree students identified their level of satisfaction between quite satisfied and satisfied. At the same, the percentage of completely dissatisfied students among the $1^{\text {st }}$-year Master's Degree students was quite lower $-2 \%$ that among the $1^{\text {st }}$-year Bachelor's Degree students $-8 \%$. The result can be seen on Figure 1 . 


\section{Satisfaction level of students with distance learning}

30

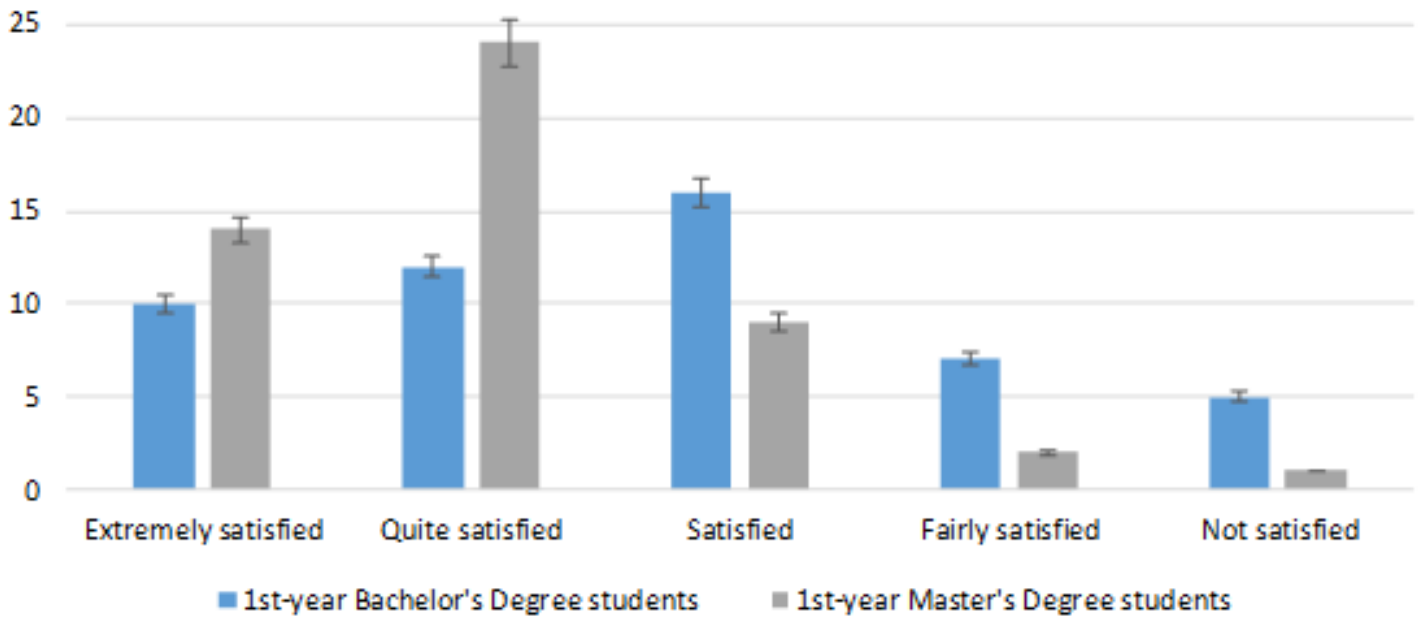

Figure 1. General satisfaction level of the $1^{\text {st }}$-year Bachelor's Degree and Master's Degree students of the Faculty of Economics of Taras Shevchenko National University of Kyiv with spring semester distance learning in 2019 - 2020 academic year (indicators are given in absolute numbers, own authorship)

The discrepancy in the opinions of the $1^{\text {st }}$-year Bachelor's and Master's Degree students demonstrates that learners of senior levels felt quite confident during the distance learning mode. This can be connected with the opportunity for them to combine a full-time job that in most cases they at this level of studying already have or the reason for this also can be their background knowledge, the level of their maturity, experience of self-study, already acquired reasoning skills as well as better developed hard and soft skills compared to those of the $1^{\text {st }}$-year Bachelor's Degree students.

The next area studied was the sufficiency of the theoretical material given during distance learning mode to the students. If $72 \%$ of the $1^{\text {st }}$-year Bachelor's Degree students equally split among those who considered it to be absolutely enough, quite enough or just enough, but $82 \%$ of the $1^{\text {st }}$-year Master's Degree students strongly believe that the theoretical material given to them during the distance mode of learning was absolutely enough or quite enough, that can be considered as a pretty high indicator. At the same time the percentage of the $1^{\text {st }}$-year Master's Degree students who felt a lack of materials given is extremely low $-2 \%$, however, $12 \%$ of the $1^{\text {st }}$-year students of Bachelor's Degree emphasized feeling scarcity of theoretical information given by the lecturers during lockdown. The results of the survey can be seen on Figure 2 . 


\section{Sufficiency of theoretical material during distance learning}

30

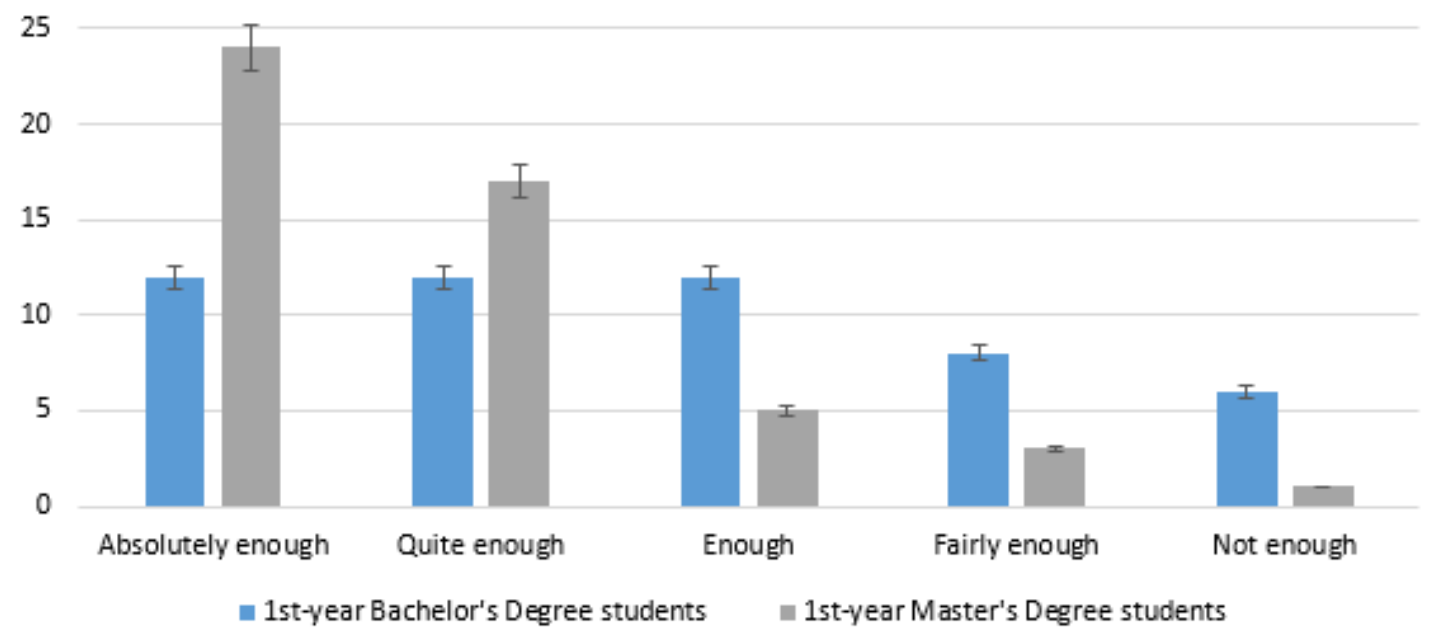

Figure 2. The level of sufficiency of the theoretical material given to the $1^{\text {st }}$-year Bachelor's Degree and Master's Degree students of the Faculty of Economics of Taras Shevchenko National University of Kyiv during spring semester distance learning in 2019 - 2020 academic year (indicators are given in absolute numbers, own authorship)

Such difference in the opinions of the students of junior and senior years of study can also be explained be the learning expertise of both categories. The $1^{\text {st }}$-year Master's Degree students had a 4-year experience of studying at university, where they were more autonomous than they were at school, where they mastered the skills of searching for the necessary material, selecting and processing it, they even were more satisfied due to having less theory, but more exposure to real-life situations, practical cases, huge amount of external resources beyond the classroom. However, the $1^{\text {st }}$-year Bachelor's Degree students, yesterday's school leavers, for that moment were lacking such competences and the experience was not enough to be able to work with scarcity of information or other resources they got from their teacher, who was expected to facilitate their learning process.

The next point of the research was connected with the pain of all the teachers in the framework of distance learning - assessment. The aim of this research was to study whether the students consider the assessment of their performance as transparent and objective. Thus, $62 \%$ of the $1^{\text {st }}$-year Bachelor's Degree students appeared to be quite satisfied or just satisfied with the way their outputs and outcomes were assessed, whereas, $88 \%$ of the $1^{\text {st }}$-year Master's Degree students demonstrated a high level of satisfaction with the assessment - between extremely satisfied and quite satisfied. $2 \%$ of the latter focus group appeared to be dissatisfied with the level of assessment, however, among the $1^{\text {st }}$-year Bachelor's Degree students this percentage of not satisfied learners appeared to be slightly higher $-8 \%$. The results of the survey can be seen on Figure 3. 


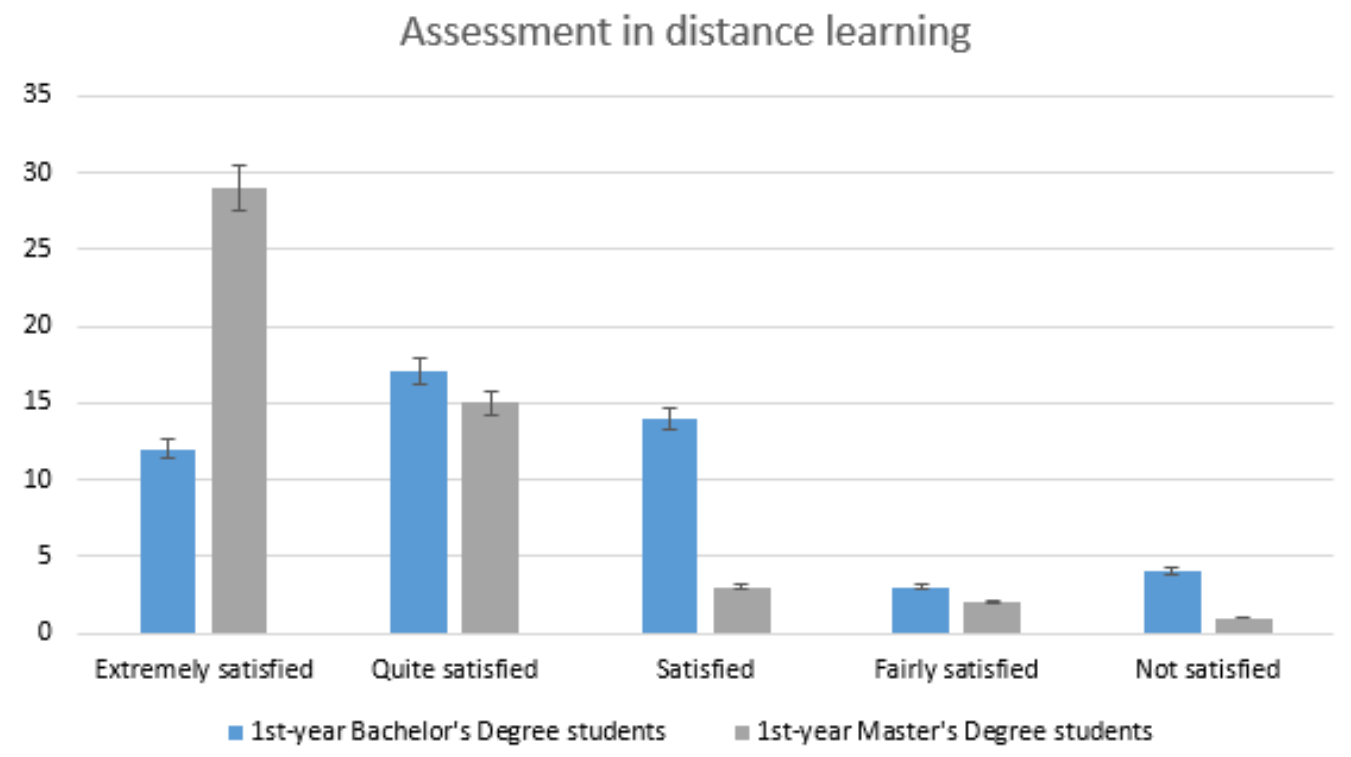

Figure 3. Satisfaction level of the $1^{\text {st }}$-year Bachelor's Degree and Master's Degree students of the Faculty of Economics of Taras Shevchenko National University of Kyiv with assessment during the spring semester distance learning in 2019 - 2020 academic year (indicators are given in absolute numbers, own authorship)

Such high percentage of the students satisfied with their assessment can be connected on the one hand with its objectivity and transparency of the criteria, but on the other hand it can be linked to the relative easiness of getting a higher grade online compared to face-to-face exam or pass-fail test. This is one of the biggest disadvantages of the distance learning in formal education, when it is almost impossible for the teachers to avoid student's cheating, using somebody's help, etc.

Trying to identify main issues of the distance learning in this research the means of remote communication between teachers and students were studied. The results can be found on Figure 4.

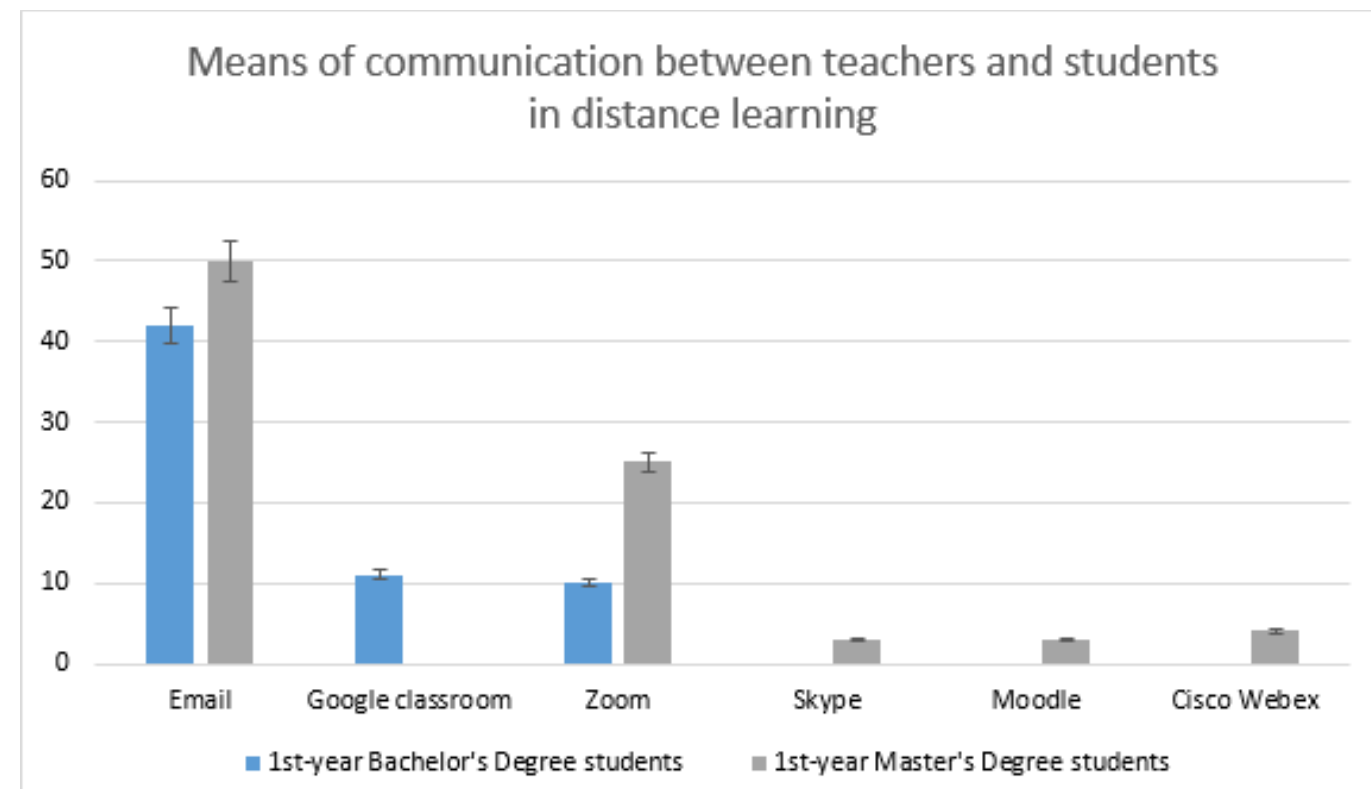

Figure 4. Means of communication between teachers and students of the Faculty of Economics of Taras Shevchenko National University of Kyiv during the spring semester distance learning in 2019 - 2020 academic year (indicators are given in absolute numbers, own authorship) 
As it can be judged from the diagram in spring the biggest amount of teachers used emails for providing the materials, giving the tasks, monitoring and evaluating the performance of the students. $100 \%$ of the $1^{\text {st }}$-year Master's Degree students and $84 \%$ of the $1^{\text {st }}$-year Bachelor's Degree students have proved this. $22 \%$ of the latter focus-group also claimed the usage of such platform for asynchronous learning as Google classroom, however, only $6 \%$ of the $1^{\text {st }}$-year Master's Degree students mentioned Moodle as the tool for the same type of learning. But if to analyze the results of the research in the framework the platforms for synchronous learning the balance is shifted for the benefit of the Master's Degree students, $64 \%$ of whom pointed out the following means as: Zoom, Skype and Cisco Webex, whereas, only $20 \%$ of the Bachelor's Degree students mentioned Zoom as the platform that was used by the teachers.

The last question of the survey was aimed at identifying the difficulties the students faced during the distance learning under total shutdown. The results of the research are demonstrated on Figure 5.

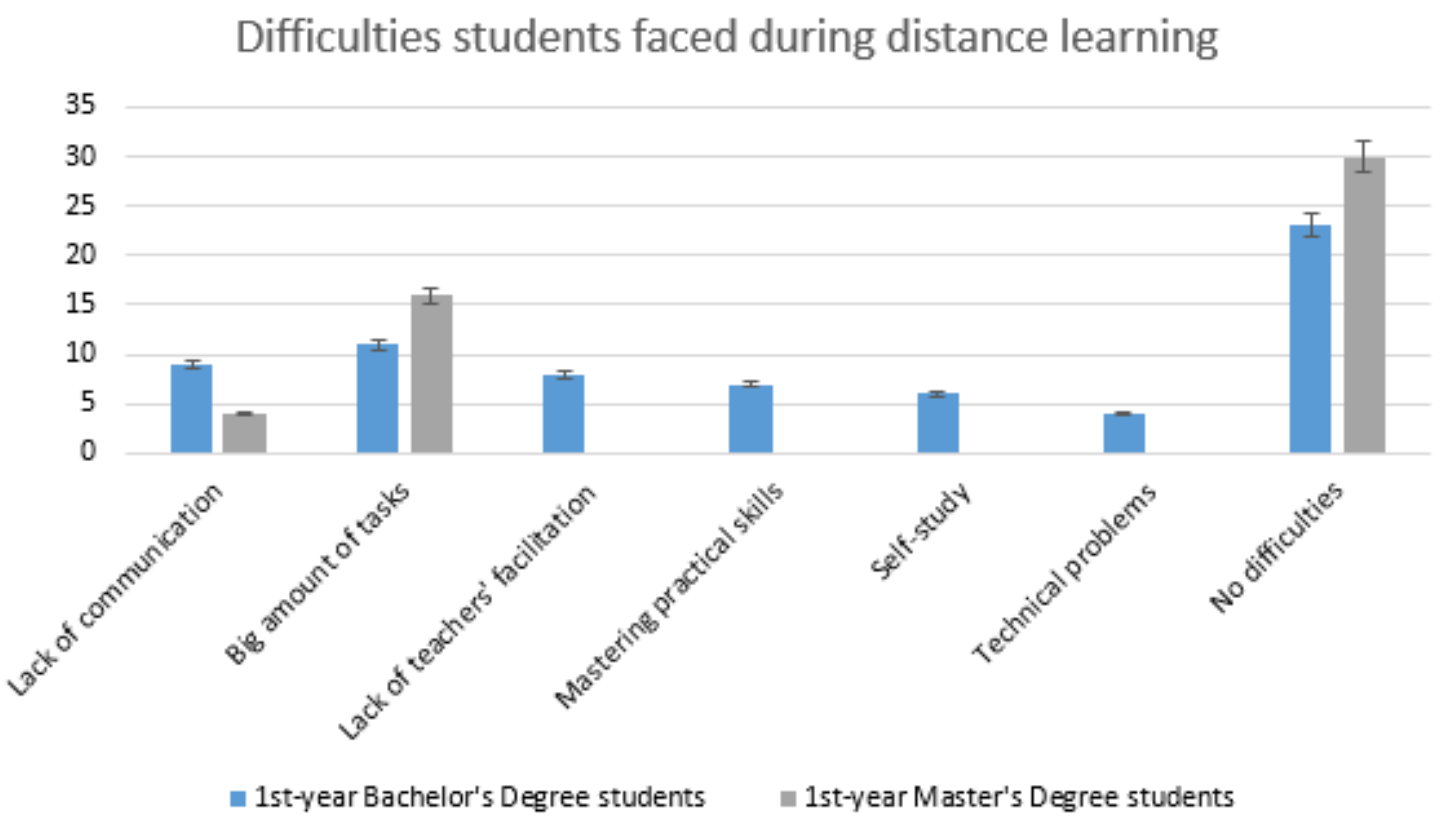

Figure 5. Difficulties the 1st-year Bachelor's Degree and Master's Degree students of the Faculty of Economics of Taras Shevchenko National University of Kyiv faced during the spring semester distance learning in 2019 - 2020 academic year (indicators are given in absolute numbers, own authorship)

As it is seen from the diagram $60 \%$ of the $1^{\text {st }}$-year Master's Degree students and $46 \%$ of the $1^{\text {st }}$-year Bachelor's Degree students have claimed having no problems with distance learning mode. However, the study has demonstrated that among the rest of the respondents senior students pointed out less challenges (only two) than the junior students, who mentioned 6 issues. Two of the enumerated problems were common for both focus groups: lack of communication with the teachers that was mentioned by $18 \%$ of the $1^{\text {st }}$-year Bachelor's Degree students as well as by $8 \%$ of the $1^{\text {st }}$-year Master's Degree students and much bigger compared to offline learning amount of tasks that was outlined by $22 \%$ of junior students and by $32 \%$ of senior students.

The $1^{\text {st }}$-year Bachelor's Degree students also pointed out the following problems: lack of teachers' facilitation (16\%), difficulties with mastering practical skills (14\%) and with self-study mode of processing information, learning, how to do sums or solve cases (12\%), also they mentioned some technical problems, linked to poor Internet connection, outdated hardware and software, etc (8\%). 
This research and more than a half of a year of distance learning experience clearly demonstrated that most of the mentioned problems and difficulties can be easily solved through the combination of platforms for synchronous and asynchronous learning, introducing bigger variety of teaching methods, increasing digital literacy of teachers via teacher trainings, webinars and master-classes. The only problem that doesn't have the exact solution is transparent and objective online assessment. Students are quite satisfied how they are assessed, because they find it much easier to get a higher grade due to violating academic integrity norms. But this is more than just a lucky situation for certain irresponsible students, this is the matter of quality assurance of higher education. However, this issue is still under consideration in academic and research community.

\section{Conclusions}

The research conducted among the $1^{\text {st }}$-year Bachelor's Degree students and the $1^{\text {st }}$-year Master's Degree students has proved that despite certain problems (lack of communication with the teachers and bigger amount of tasks) senior students are absolutely happy with distance learning mode. This type of the learning process is more flexible and allows them to combine a full-time job with doing Master's Degree at the University. Their background knowledge, expertise, learning experience, already obtained hard and soft skills allow them to require less facilitation from the teacher, to easily find the necessary information in the Internet and other resources, to analyze and process this information, to draw the conclusions, to find and to fix the mistakes, to remotely work with their peers on a number of projects. However, the $1^{\text {st }}$-year Bachelor's Degree students are not ready to have only distance learning. They still need some facilitation from their teachers in terms of explaining certain theoretical material, providing them with the necessary resources, helping them to develop certain hard and soft skills. That was proved by the current research findings, that demonstrated a relatively average level of their satisfaction compared to the $1^{\text {st }}$-year Master's Degree students, who appeared to be fully satisfied with online learning. Thus, though the problem with quality and reliability of online procedures of assessment is not solved yet, the most beneficial forms of educational process for the Master's Degree students seems to be distance learning, however, for the $1^{\text {st }}$-year Bachelor's Degree students learning still requires offline or at least blended format.

\section{Bibliographic references.}

Arkorful, V., and Abaidoo, N. (2015) The role of e-learning, advantages and disadvantages of its adoption in higher education. International Journal of Instructional Technology and Distance Learning. 12 (1). Pp. $22 \quad-\quad 42 . \quad$ Retrieved from https://www.itdl.org/Journal/Jan_15/Jan15.pdf\#page=33

Arbeláez-Campillo, D., \& Rojas-Bahamon, M. (2020). Pandemics in globalization times. Amazonia Investiga, 9(27), 3-4. https://doi.org/10.34069/AI/2020.27.03.0

Basilaia, G., Dgebuadze, M., Kantaria, M., Chokhonelidze, G. (2020) Replacing the Classic Learning Form at Universities as an Immediate Response to the COVID-19 Virus Infection in Georgia. from https://www.researchgate.net/profile/Marine_Dgebuadze/publication/339740614_Repla cing_the_Classic_Learning_Form_at_Universities_as_an_Immediate_Response_to_the COVID-

19_Virus_Infection_in_Georgia/links/5e623d3b4585153fb3c500c8/Replacing-theClassic-Learning-Form-at-Universities-as-an-Immediate-Response-to-the-COVID-19Virus-Infection-in-Georgia.pdf

Bennardo, F., Buffone, C., Fortunato, L., Giudice, A. (2020). COVID-19 is a challenge for dental education—A commentary. https://onlinelibrary.wiley.com/doi/full/10.1111/eje.12555 
Borodavko, L., Silkin, N., Shakhmatov, A., \& Chelysheva, O. (2020). Organization of Education Using Modern Distance Learning Technologies in the Context of the COVID-19 Pandemic (on the example of Russian law schools). Amazonia Investiga, 9(33), 51-58. https://amazoniainvestiga.info/index.php/amazonia/article/view/1488 https://doi.org/10.34069/AI/2020.33.09.6

Bostan, S., Erdem, R., Öztürk, Y., Kılıç, T., Yılmaz, A. (2020) The Effect of COVID-19 Pandemic on the Turkish Society. Retrieved from https://www.ejgm.co.uk/download/theeffect-of-covid-19-pandemic-on-the-turkish-society-7944.pdf

Brom, C., Lukavský, J., Greger, D., Hannemann, T., Straková, J., and Švaříček, R. (2020) Mandatory Home Education During the COVID-19 Lockdown in the Czech Republic: A Rapid Survey of 1st-9th Graders' Parents. Retrieved from https://www.frontiersin.org/articles/10.3389/feduc.2020.00103/full?fbclid=IwAR1XjPY VHi7puCILHJcyRDEV09UW4GMN4c_VKpvaR_yQnrxLbn8onE4excY

Czerniewicz, L. (2020) What we learnt from "going online" during university shutdowns in South Africa. Retrieved from https://philonedtech.com/what-we-learnt-from-going-onlineduring-university-shutdowns-in-south-africa/

Domenici, V. (2020) Distance Education in Chemistry during the Epidemic Covid-19. Retrieved from file:///C:/Users/Owner/Downloads/961-Article\%20Text-5360-1-10-20200624.pdf

Howard, R., \& McGrath. I. (1995). Distance Education for Language Teachers: a UK Perspective. (1995). Avon, Bristol, Adelaide: Ed. Multilingual Matters LTD. Pp. 15 - 18. Retrieved from

https://books.google.com.ua/books?hl=ru\&lr=\&id=LZlhKWDjoEAC\&oi=fnd\&pg=PA1 $4 \& d q=a d v a n t a g e s+o f+d i s t a n c e+l e a r n i n g \& o t s=Z i y z G y A z M c \& s i g=z b c W B l w 81 l d E S q 0 t$ EPTAWurdNHg\&redir_esc $=\mathrm{y} \# \mathrm{v}=$ onepage $\& \mathrm{q}=$ advantages $\% 20 \mathrm{of} \% 20$ distance $\% 201$ earni $\mathrm{ng} \& \mathrm{f}=\mathrm{false}$

Hilburg, R., Patel, N., Ambruso, S., Biewald, M. A., Farouk, S.S. (2020) Medical Education During the Coronavirus Disease-2019 Pandemic: Learning From a Distance Retrieved from https://www.sciencedirect.com/science/article/pii/S154855952030094X

Hodges, Ch., Moore, S., Lockee, B., Trust, T., and Bond, A. (2020) The Difference Between Emergency Remote Teaching and Online Learning. Retrieved from https://er.educause.edu/articles/2020/3/the-difference-between-emergency-remoteteaching-and-online-learning

Mohammad, A. (2020) COVID-19 and higher education Economics. Retrieved from https://search.proquest.com/openview/3fe4d9cd3ad206407fed9117e2153d9a/1?pqorigsite $=$ gscholar $\& \mathrm{cbl}=38746$

Moroz, Y., Gordienko, T., Hrabrova, V., \& Medvedeva, O. (2019). Distance learning in Russia in the context of learning foreign languages. Amazonia Investiga, 8(22), 280-285. Retrieved from https://amazoniainvestiga.info/index.php/amazonia/article/view/432

Murphy, M. (2020) COVID-19 and emergency eLearning: Consequences of the securitization of higher education for post-pandemic pedagogy, Contemporary Security Policy, 41:3, 492505, DOI: 10.1080/13523260.2020.1761749

Myths About Online Learning: It's Not the Emergency Remote Instruction Your Kids Received This Spring (2020). Retrieved from https://www.wbtsystems.com/learninghub/blogs/myths-about-online-learning-pandemic 
Ocak, M. (2020) What we learned about distance education during Covid-19? Retrieved from https://epale.ec.europa.eu/en/blog/what-we-learned-about-distance-education-duringcovid-19

O'Lawrence, H. (2005) A Review of Distance Learning Influences on Adult Learners: Advantages and Disadvantages. Retrieved from http://citeseerx.ist.psu.edu/viewdoc/download?doi=10.1.1.555.7558\&rep=rep1\&type $=p$ df

Posey, G., Burgess, T., Eason, M., Jones, Y. (2010) The Advantages and Disadvantages of the Virtual Classroom and the Role of the Teacher. Retrieved from http://swdsi.org/swdsi2010/SW2010_Preceedings/papers/PA126.pdf

Radović-Marković, M. (2010) Advantages and disadvantages of e-learning in comparison to traditional forms of learning. Annals of the University of Petroşani, Economics. 10(2). Pp. 289 - 298 Retrieved from https://www.researchgate.net/profile/Nicolae_Ecobici/publication/49965686_TAX_AN D_ACCOUNTING_IMPLICATIONS_OF_THE_USE_OF_SPECIAL_CHARGE_SCH EME_FOR_SECOND-

HAND_GOODS_TO_THE_PAWN_SHOPS_IN_ROMANIA/links/5693b4a808ae820f f0727953/TAX-AND-ACCOUNTING-IMPLICATIONS-OF-THE-USE-OFSPECIAL-CHARGE-SCHEME-FOR-SECOND-HAND-GOODS-TO-THE-PAWNSHOPS-IN-ROMANIA.pdf\#page $=289$

Rizun, M., Strzelecki, A. (2020) Students' Acceptance of the COVID-19 Impact on Shifting Higher Education to Distance Learning in Poland. Retrieved from https://www.mdpi.com/1660-4601/17/18/6468

Santana de Oliveira, M.M., Torres Penedo, A.S (2018) Distance education: advantages and disadvantages of the point of view of education and society. Retrieved from https://www.researchgate.net/profile/Antonio_Penedo2/publication/328032761_Distanc e_education_advantages_and_disadvantages_of_the_point_of_view_of_education_and_ society/links/5ce5b3a4299bf14d95b1ce3a/Distance-education-advantages-anddisadvantages-of-the-point-of-view-of-education-and-society.pdf

Shyshatskiy, Y. (2020) How it was. More scaring than Coronavirus. History off flue covered the World and Ukraine ten years ago (ukr.) Retrieved from https://tech.liga.net/technology/article/strashnee-koronavirusa-istoriya-grippanakryvshego-mir-i-ukrainu-desyat-let-nazad 